\title{
PENYULUHAN UNTUK IBU RUMAH TANGGA DI LUNJUK JAYA RT.30 RW.10 KELURAHAN LOROK PAKJO KECAMATAN ILIR BARAT I PALEMBANG TENTANG BIODISEL DARI LIMBAH IKAN
}

\author{
Masayu Anisah ${ }^{1}$, Evelina ${ }^{2}$, Abdurrahman $^{3}$, Nyayu Latifah Husni ${ }^{4}$ \\ ${ }^{1,4}$ Sarjana Terapan Teknik Elektro, Jurusan Teknik Elektro, Politeknik Negeri Sriwijaya \\ ${ }^{2,3}$ Teknik Elektronika, Jurusan Teknik Elektro, Politeknik Negeri Sriwijaya \\ masayu_anisah@polsri.ac.id
}

\begin{abstract}
Abstrak
Program Pengabdian Masyarakat Kerjasama Dosen mahasiswa (PPM_KDM) adalah Penyuluhan untuk ibu rumah tangga tentang biodisel dari limbah ikan. Pengabdian ini menitik beratkan pada pemanfaatan limbah ikan yang ada di sekitaran Pasar 26 Ilir Palembang. Limbah ikan biasanya menjadi salah satu penyebab pencemaran lingkungan dengan bau menyengat dan sangat mengganggu akibat kerumunan lalat. Kategori limbah adalah sampah. Pengabdian ini memfokuskan melakukan penyuluhan disertai demo lagsung tentang bagaimana mengolah limbah ikan hingga menjadi bahan bakar. Objek penyuluhan adalah ibu rumah tangga di RT.30/10 Lunjuk Jaya. Tahapan kegiatan ini di lakukan mulai bulan Agustus sampai dengan bulan Desember 2016. Dimana peserta penyuluhan terdiri dari 20 sampai 25 orang masyarakat. Tahap - tahap pengabdian ini yaitu Pra interaksi, Introduksi atau Orientasi, Kerja, Terminasi proses, dan Terminasi akhir.
\end{abstract}

Kata Kunci: biodiesel, limbah, ikan, penyuluhan

ABSTRACT: Community Service Program for Student Lecturer Cooperation (PPM_KDM) is counseling for housewives about biodiesel from fish waste. This dedication focuses on the utilization of waste fish in the vicinity of Pasar 26 Ilir Palembang. Fish waste is the cause of environmental pollution with a large number of odor and very structured due to the flies. The waste category is fish garbage. This service is focused on making changes to processes fish waste into fuel. The object of learning is a housewife at RT.30/10 Lunjuk Jaya. The activities were conducted from August to December 2016. Where the extension participants consisted of 20 to 25 community members. These stages of service are Pre-Interaction, Introduction or Orientation, Work, Process Termination, and Final Termination.

Keywords: biodiesel, waste, fish, extension

\section{PENDAHULUAN}

Palembang adalah kota terbesar kedua di Sumatera setelah Medan. Kota Palembang memiliki luas wilayah $358,55 \mathrm{~km}^{2}$ yang dihuni 1,7 juta orang dengan kepadatan penduduk 4.800 per $\mathrm{km}^{2}$. Diprediksikan pada tahun 2030 mendatang Kota ini akan dihuni 2,5 Juta orang. Palembang sebagai kota Empek-empek merupakan salah satu kota yang dikelilingi sungai. Sebagian besar sungai memiliki keaneka ragaman ikan yang bisa dikonsumsi masyarakat disekitarnya.

Berbagai olahan makanan tediri dari bahan dasar daging ikan. Sisa - sisa olahan berupa tulang ikan sering diabaikan dan dibuang. Pemanfaatan sisa - sisa tulang ikan tersebut sebagai bahan baru dan terbaharukan yang dapat di ubah menjadi energy alternatif yaitu cikal bakal bahan bakar minyak seperti Biodiesel atau solar [1].

Energi dalam bentuk bahan bakar menjadi andalan untuk melaksanakan aktivitas. Ketidaktersediaan sumber energi itu menjadi kendala dalam keseharian masyarakatkota Palembang, Sumatera Selatan. Kita dapat menyaksikan saat harga bahan bakar naik, maka orang-orang antri untuk memperolehnya.

Belum lagi jika harganya mahal karena sulit diperoleh ini menyusahkan masyarakat pedesaan yang bergantung pada bahan bakar minyak solar untuk kebutuhan alat-alat pertanian mereka, seperti mesin traktor, mesin generator dan lain-lain.Namun, jika kita menelaah lebih dalam terhadap lingkungan sekitar, banyak sekali limbah yang bisa kita ubah dan kita dapatkan dengan mudah. Hal tersebut sebagai pengganti dan penyeimbang terhadap pemakaian sumber daya alam yang tidak dapat diperbaharui atau pemakaian bahan bakar fosil [2].

Maka dari itu, masalah yang diangkat mengenai sosialisasi pemanfaatan biodiesel sebagai energi alternatif pengganti bahan bakar fosil yang mudah diperoleh dan sebagai solusi dari permasalahan banyaknya Gas Elpigi yang meledak serta meroketnya harga minyak tanah di pasaran. Diharapkan sedikit demi sedikit polusi udara yang menyebabkan kerusakan pada lapisan ozon dapat dikurangi, karena biodiesel dari 
limbah ikan memiliki emisi gas buang yang lebih sedikit dibandingkan dengan bahan bakar fosil.

\section{IDENTIFIKASI MASALAH}

Palembang sebagai kota Empek-empek merupakan salah satu kota yang memproduksi ikan terbanyak diIndonesia. Sisa-sisa hasil produksi tersebut kemudian dibiarkan begitu saja atau dibuang sebagai limbah. Padahal limbah tersebut dapat kita ubah menjadi energi bahan bakar minyak salah satunya yaitu Biodiesel.

Sumber daya alam dibagi menjadi dua yaitu sumber daya yang dapat diperbarui dan sumber daya yang tidak dapat diperbarui. Sumber daya yang tidak dapat diperbaharui ialah sumber daya yang apabila digunakan secara terus-menerus akan habis contohnya barang tambang yang ada di dalam perut bumi seperti minyak bumi, batu bara, timah, nikel, dan lain-lain. Kita harus menggunakan sumber daya ini seefisien mungkin sebab sumber daya ini akan terbentuk kembali setelah jutaan tahun kemudian.

Ketidaktersediaan sumber energi dapat menjadi kendala dalam menjalani aktivitas keseharian kita.Kita dapat menyaksikan saat harga bahan bakar naik, maka orang-orang antri untuk memperolehnya.Belum lagi jika harganya mahal karena sulit diperoleh. Dari sisi lain juga terkadang hal ini dapat menimbulkan masalah yang lebih kompleks. Namun, jika kita menelaah lebih dalam terhadap lingkungan sekitar, banyak sekali limbah yang bisa kita dapatkan dengan mudah serta kita manfaatkan sebagai pengganti dan penyeimbang terhadap pemakaian bahan bakar fosil.

Limbah tersebut kemudian dapat kita olah menjadi Biodiesel. Namun, sebagian masyarakat Indonesia tidak mengetahui akan keberadaan energi alternatif tersebut. Namun, kemungkinan itu dapat diantisipasi jika kita bisa melakukan gerakan hemat energi secara nasional.

Pengabdian pada masyarakat merupakan salah satu penunjang yang wajib dilakukan oleh setiap dosen untuk melaksanakan pengabdian pada masyarakat yang diintegrasikan dengan mahasiswa inibermaksud untuk mengurangi konsumsi energi dan menggunakannya secara efisien. Selain itu, pengalihan suplai energi kepada sumber energi baru terbarukan yang lebih ramah lingkungan juga harus segera diwujudkan. Tujuannya untuk pencegahan krisis energi, penghematan biaya, dan kelestarian lingkungan di RT 30/10 kelurahan Lorok Pakjo Palembang.

Tujuan dari pelaksanaan ini adalah Mengubah paradigma sampah tulang ikan menjadi bahan bakar alternatif yaitu biodisel. Memberikan tambahan ilmu pengetahuan dan teknologi biodisel kepada para ibu-ibu rumah tangga di RT.30 RW.10 tentang pengolahan sampah tulang ikan menjadi energi alternatif. Serta memberikan informasi mengenai pemanfaatan biodisel sebagai sumber energi alternatif yang berguna untuk masyarakat.

Manfaat dari kegiatan ini adalah menambah wawasan untuk para ibu-ibu rumah tangga di RT.30 RW.10, menambah pengetahuan tentang biodisel sebagai energy alternatif, serta mensosialisasikan pengembangan IPTEK yang berguna untuk kepentingan masyarakat.

\section{METODELOGI PELAKSANAAN}

Tahapan dalam pemecahan masalah untuk program penyuluhan ini, ada beberapa hal yang harus dilakukan, yaitu :

a. Menentukan tujuan permasalahan

b. Menjelaskan sekilas tentang biodisel dan kaitannya dengan bahan bakar

c. Memperkenalkan energi alternatif yang berasal dari limbah ikan

d. Melakukan eksperimen dan percobaan pembuktian bahwa daur ulang limbah ikan dapat dimanfaatkan menjadi tenaga bio-solar

e. Mensosialisasikan ilmu pengetahuan tentang biodisel kepada masyarakat terutama dilingkungan RT.30 Rw.10 Lunjuk Jaya Palembang.

3.1. Permasalahan biodisel dari limbah ikan ini adalah untuk menjawab pertanyaan pertanyaan:

1. Tentang permasalahan jenis limbah ikan yang dapat diolah menjadi bahan bakar / biodisel.

2. Tentang permasalahan waktu yang dibutuhkan untuk proses pengolahan limbah ikan sampai menjadi biodiesel.

\subsection{Biodisel sebagai bakar bakar diesel}

Biodiesel merupakan suatu energi alternatif yang bisa digunakan sebagai bahan bakar layaknnya bahan bakar fosil. Biodiesel diperoleh dari minyak nabati ataupun minyak hewani, sehingga bersifat dapat diperbaharui. Karena Biodiesel merupakan minyak nonfosil maka sudah tentu hasil pembakarannya bebas dari sulfur dan senyawa aromatik. Kali pertama biodiesel diujicoba pada tahun 1893 dan meraih penghargaan tertinggi di Paris tahun 1900. Seiring waktu, dengan berlangsungnya revolusi industri yang kemudian disusul oleh perang dunia maka terjadi percepatan pada kebutuhan bahan bakar. Akibatnya bahan bakar dari minyak nabati kemudian diganti dengan minyak bumi [3][4]

\section{Pembuatan Biodiesel}

Biodiesel dibuat melalui proses kimia yang disebut sebagai transesterifikasi yaitu pemisahan gliserin dari minyak nabati atau hewani. Secara sederhana, biodiesel didapat dengan mereaksikan minyak nabati atau hewani dengan alkohol (methanol) dengan bantuan hidroksida kuat $(\mathrm{NaOH})$ sebagai katalisnya. Dari prose situ akan dihasilkan produk biodiesel (metil ester), nama kimia dari biodiesel, dan gliserin. Produk sampingan inipun merupakan 
bahan yang sangat berguna misalnya sebagai bahan dasar sabun dan aneka produk lain[5][6].

\section{Keuntungan Biodiesel}

Ada berbagai keuntungan yang dapat diperoleh dengan menggunakan biodiesel, yang antara lain adalah sebagai berikut [7][8] :

a) Keuntungan Ekonomis, dengan Biodiesel belanja energi nasional bisa dikurangi yaitu dengan mensubstitusikan bahan bakar fosil dengan bahan bakar biodiesel yang notabene harganya tidak kalah kompetitif, untuk beralih kebahan bakar biodiesel tidak diperlukan tambahan biaya untuk mengganti mesin, perawatan, dan maintenance lainnya, dan membebaskan diri dari ketergantungan akan minyak bumi yang nyata-nyata harganya terus melambung.

b) Keuntungan Dari Segi Lingkungan, emisi dari hasil pembakaran biodiesel lebih bersih dari sisa pembakaran bahan bakar senyawa ataupun gas dari bahan bakar fosil,penelitian mencatat bahwa biodiesel terbukti bisa menurunkan kadar emisi hidrokarbon sampai $67 \%$ lebih rendah dibanding solar dan mengurangi emisi gas karbonmonoksida sampai level 48\% lebih rendah dibandingkan emisi ga $\mathrm{s}$ buang dari yang menggunakan bahan bakar solar.

Jadi, biodiesel merupakan bahan bakar alternatif
yang ramah lingkungan, karena hasil
pembakaran dari biodiesel tidak mengandung
bahan-bahan berbahaya seperti halnya
pembakaran dari bahan bakar fosil.

\subsection{Energi alternatif yang berasal dari limbah ikan}

Potensi limbah ikan sangat besar. Sebagai gambaran volume limbah pelelangan ikan di Muncar, Jawa Timur mencapai 50-60 ton per bulan. Namun dari jumlah tersebut tidak semuanya dapat dimanfaatkan sepenuhnya. Di rumah tangga masyarakat banyak sekali sisa-sisa ikan yang tidak terpakai seperti isi perut ikan, kepala dan tulang. Selain itu di daerah pelelangan ikan juga banyak terdapat ikan yang tidak dimanfaatkan seperti jenis ikan yang tertangkap namun tidak memiliki nilai ekonomis.

\subsection{Eksperimen Dan Percobaan}

Limbah merupakan bahan sisa yang dihasilkan dari suatu kegiatan atau proses produksi, baik pada skala rumah tangga, industri, pertambangan, dan sebagainya. Bentuk limbah dapat berupa gas, debu, cair atau padat.

Sisa-sisa ikan tersebut yang dapat berupa isi perut, kepala, tulang bahkan seluruh bagian tubuh ikan dan ikan yang busuk sekalipun berpotensi untuk dapat di gunakan dan diolah kembali menjadi bahan bakar. Ikan memiliki kandungan gizi dan juga kandungan kimia. Kandungan gizi yang terdapat pada ikan patin (Pangasius hypophthalamus) misalnya yaitu, protein $68,6 \%$; lemak 5,8\%; abu 5\%; air 59,5\%. Sedangkan komposisi kimia ikan patin yaitu, kadar air 82,2\%; kadar abu $0,74 \%$; protein $14,54 \%$; lemak $1,09 \%$, karbohidrat
$1,43 \%$. Selain itu berbandingan lemak, protein, dan kalori yaitu $2 \%: 65 \%: 45 \%$.

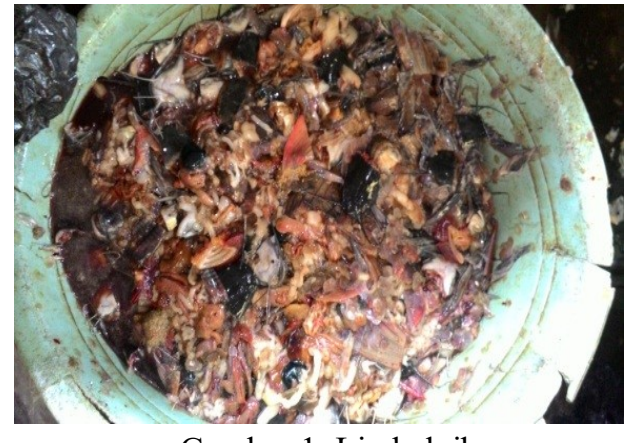

Gambar 1. Limbah ikan

\section{Cara Pembuatan}

1. Campurkan metal alkohol atau methanol dengan $\mathrm{NaOH}$ sampai keduanya larut, hasil pencampuran itu dinamakan methoksid.

2. Panaskan limbah ikan yang sudah di blender. Proses pemanasan ini akan menghasilkan 2 lapisan yaitu minyak ikan dan sisa limbah ikan. Lalu pisahkan bagian minyak ikan.

3. Panaskan minyak ikan hingga bersuhu $50^{\circ} \mathrm{C}$.

4. Reaksikan methoksid dengan menuangkannya kedalam minyak ikan yang sudah dipanaskan tersebut. Aduk hingga merata (bisa juga di aduk dengan blender) kira-kira selama 30 menit-60 menit dengan kecepatan rendah.

5. Tuangkan hasil pencampuran tadi kedalam gelas kimia. Diamkan selama 12-24 jam. Disitu akan didapatkan biodiesel yang sudah terpisah dari glyserin.

6. Lanjutkan dengan proses pemisahan. Hati-hati jangan sampai gliserin terbawa bersama biodiesel sewaktu proses pemisahan.

7. Cuci biodiesel tersebut dengan air yang telah dicampur dengan asam cuka. Aduk menggunakan mixer. Ciri keduanya telah tercampur adalah warnanya menjadi kuning seperti susu.

8. Diamkan sejenak selama 1 jam sehingga biodiesel terpisah dari air . Biodiesel akan terletak di lapisan atas sementara larutan air menempati bagian bawah.

9. Pisahkan biodiesel dari air dengan hati-hati kedalam botol.

10. Hasil biodiesel yang dipisahkan tersebut campurkan dengan aquades dan aduk dengan proses pengadukan manual. Ulangi langkah tersebut hingga 4 kali.

11. Proses pencucian boleh dihentikan bila air bilasan sudah tidak keruh lagi atau PHnya sudah netral (PH 7).

\subsection{Sosialisasi}

Proses kegiatan sosialisasi berupa penyuluhan dengan tahapan : Survei ke lokasi sumber limbah tulang ikan, survei ke lokasi RT.30 Rw.10 Lunjuk Jaya Palembang, proses persiapan awal tim penyuluh, proses 
persiapan pelaksanaan penyuluhan hingga proses akhir yaitu pelaporan ke lembaga pendidikan Politeknik Negeri Sriwijaya.

Program ini dibuat untuk Ibu-Ibu Rumah Tangga di Lunjuk Jaya Rt.30 RW.10 Palembang. Pada pelaksanaannya nanti berisi teori dan praktek mengenai pembuatan bio-solar dengan menggunakan limbah ikan yang di mulai dari pengenalan bahan, alat yang di butuhkan, hingga proses pembuatan dari awal hingga akhir sampai menjadi solar.

\section{HASIL DAN PEMBAHASAN}

Adapun metode yang digunakan dalam penyuluhan pemanfaatan limbah ikan menjadi bio-solar ini adalah :

\section{a. Teori}

Dalam penyuluhan biodisel dari limbah ikan ini dibutuhkan dasar pengetahuan tentang seluk-beluk solar dan limbah ikan. Sehingga memudahkan peserta untuk memahami proses pembelajaran.

\section{b. Praktek}

Untuk menunjang penyuluhan solar dari limbah ikan maka dibutuhkan sebuah kegiatan pengalaman langsung yaitu berupa praktek. Dengan metode praktik maka peserta mampu melakukan simulasi dan menerapkan apa yang telah dipelajari dalam teori.
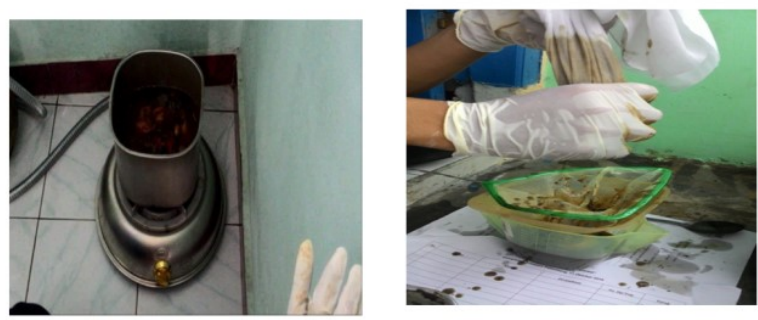

Gambar 2. Hasil Perasan limbah Ikan 1x

Selanjutnya hasil limbah yang sudah disaring diolah dengan mencapurkan cairan metanol dan $\mathrm{H} 2 \mathrm{SO} 4$ dengan perbandingan minyak, metanol dan $\mathrm{H} 2 \mathrm{SO} 4$ sebesar $2: 3: 3$. Selanjutnya bahan diaduk rata hingga \pm 30 menit untuk memperoleh minyak dan gliserin.

Minyak Hasil Dipisahkan dengan gliserin, lalu minyak dicampur dengan $\mathrm{H} 2 \mathrm{SO} 4$. Untuk memisahkan minyak dengan sisa-sisa air, ditambahkan aQuades.

Berdasarkan percobaan yang telah dilakukan dan dapat dilihat pada table 3.1 bahwa daya nyala biodiesel limbah ikan lebih rendah jika dibandingkan dengan minyak lampu. Hal ini dikarenakan nilai panas minyak ikan dibawah minyak tanah. Nilai panas minyak ikan $9.270 \mathrm{kal} / \mathrm{g}$ sedangkan minyak tanah $11.000 \mathrm{kal} / \mathrm{g}$ dan kandungan air minyak limbah ikan lebih tinggi dibandingkan minyak tanah yaitu 10,4\%:2,5\%.
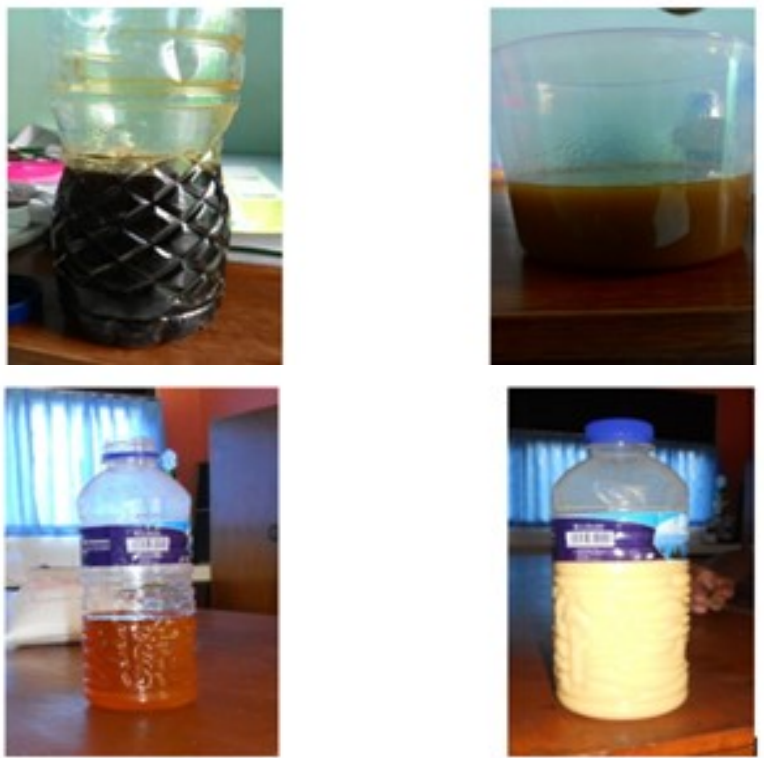

Gambar 3. Minyak Ikan Hasil Perasan

Hasil dari percobaan yang telah dilakukan dapat disimpulkan bahwa kecepatan nyala api yang menggunakan Biodiesel Limbah ikan lebih rendah jika dibandingkan dengan kecepatan nyala api yang menggunakan Minyak Tanah. Hal ini disebabkan karena pada saat api dinyalakan dan di hubungkan terhadap sebatang katu kecil yang telah di celupkan pada masing masing minyak, ternyata api tersebut lebih cepat menyambar kayu yang telah di celupkan pada minyak tanah. Sedangkan biodiesel limbah ikan tidak cepat menyambar apinya.

Setelah didapatkan minyak ikan yang telah dipisahkan dengan gliserin lalu, cuci biodiesel tersebut dengan air yang telah dicampurkan dengan asam cuka. Setelah itu diamkan selama 1 jam hingga biodiesel terpisah dengan air. Setelah biodiesel minyak ikan terpisah dari lapisan air, dilakukan pencucian dengan menambahkan aquades pada biodiesel minyak ikan. Proses pencucian ini dilakukan hingga 4 kali sampai air pencucian netral (PH7).

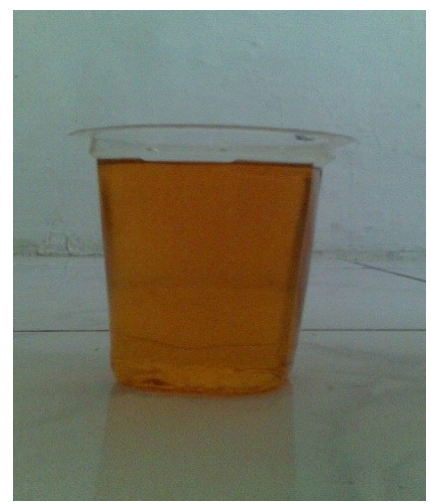

Gambar 4. Biodiesel Minyak Ikan yang Murni 


\section{KESIMPULAN}

Berdasarkan hasil Penyuluhan untuk Ibu-ibu Rumah Tangga di Lunjuk Jaya RT.30 RW.10 Palembang Tentang Pemanfaatan Limbah Ikan menjadi Bio-solar, maka dapat diambil kesimpulan sebagai berikut :

1. Menambah wawasan dan pengetahuan tentang teknologi biodisel kepada Ibu-ibu Rumah Tangga di Lunjuk Jaya RT.30 RW.10 Palembang.

2. Memberikan informasi tentang pemannfaatan biodisel sebagai sumber energi alternatif yang berguna untuk masyarakat.

\section{REFERENSI}

[1] Balitbang Sumsel. 2014. Data Kebutuhan Ikan kota Palembang. (balitbangnovdasumsel.com /data/ download/20140203110945.pdf. Diakses pada 9 Agustus 2015).

[2] Manai, Syamsudin. 2010. Membuat Sendiri Biodiesel. Yogyakarta: Lily publisher.

[3] [2]. W.P, Suryo dan Rochim Armando. 2005. Membuat kompor Tanpa BBM. Jakarta:Penebar Swadaya.

[4] Fitriani, Vina. 2008 .Bahan Bakar dari Limbah Ikan. (dalam Trubus, Edisi Juni 2008). Jakarta: Trubus Media Swadaya.

[5] Miyati. 2011. pengolahan limbah ikan efektif dan efisien.(https://miyanti.wordpress.com/2011/10/29/ pengolahan-limbah-ikan-efektif-dan-efisiennya/. Diakses pada tanggal 8 Agustus 2015).

[6] Anonim. 2013. fakta menarik tentang biodiesel yang perlu diketahui. (http://www.amazine.co/26965/15-fakta-menariktentang-biodiesel-yang-perlu-diketahui/. Diakses pada tanggal 8 Agustus 2015).

[7] Anonim. 2014. potensi boodiesel untuk subtitusi. (http://www.esdm.go.id/berita/37-umum/459potensi-biodiesel-untuk-substitusi. Diakses pada tanggal7 Agustus 2015).

[8] Beranda Miti. 2013. Mengenal Biodiesel. (http://beranda-miti.com/mengenal-biodiesel/.

Diakses pada tanggal 9 Agustus 2015). 